\title{
Land rights in postwar Liberia: the volatile part of the peace process
}

\author{
Jon D. Unruh \\ McGill University
}

\begin{abstract}
The end to the war in Liberia, along with quality leadership and a large UN presence has laid the foundation for a successful peace process. Now the delicate part of the process is underway - building viable, equitable, and durable social relations, institutions and legal constructs. A potentially volatile part of any postwar scenario is the inability of land rights institutions to perform in an effective, legitimate, equitable manner. Reform of land tenure via policies, laws, institutions, and capacity, needs to happen in a manner that is able to attend to both the land rights related causes of conflict, and the tangle of land problems brought on by the war itself. This article reports on the current situation in Liberia, and examines the primary set of land tenure problems in the country. The article concludes with a series of suggestions for dealing with the unique circumstances of postwar land tenure, and the Liberian case.
\end{abstract}

Keywords: Postwar, land tenure, Liberia, Africa, rule of law, peace process

\section{Introduction}

A generally successful postwar disarmament and demobilization but ongoing reintegration effort in Liberia has now thrust other issues to the fore; particularly those that contributed to the cause of the conflict, and continue to operate in a volatile manner. Land rights in particular are a concern, and the potential exists that contentious land issues could degenerate into extremely problematic situations if not addressed in a timely, effective fashion (Daygbor, 2007; Banks, 2006; Johnson, 2007; Zelze, 2007). The President of Liberia has "expressed fear that the issue of land reform, if not swiftly redressed by the government and its international partners, could crop up into another war in the country" (Daygbor, 2007). In particular she has noted in recent speeches "that land reform is needed now to contain future troubles", and that "land disputes are a major hurdle in the wake of attaining genuine peace in the country" (Daygbor, 2007).

In Liberia the central role that land tenure issues had in the cause and maintenance of the conflict, and the acutely problematic state of the issue currently, is well recognized (Richards, et al. 2004; Richards, 2005; World Bank, 2007; GRC, 2007; Unruh, 2007b). Discontent over land issues, together with the exploitation of rural labor, led to the largescale disenfranchisement and mobilization of rural youth, to the degree that they comprised the majority of the fighters in the war (Richards, 2005). Prior to the conflict the enduring rural systems of clientage and deference, supported by forms of indirect rule, generated an accumulation of rural underclass grievances to produce a crisis of 
agrarian institutions (Richards, 2005). At the same time poor governance precluded the peaceful derivation of alternative, legitimate, and equitable institutions and approaches (Sawyer, 2005). Land grabbing over time by powerful urban and rural elites operated within an archaic, neglected, and discriminatory customary tenure system. And coupled with the inability of the non-elite (primarily youth) to acquire and maintain control of land and (their own) labor, the result was the generation of deep animosities that were not resolved by the signing of the peace accord that officially marked the end of the Liberian conflict. Nor have they been attended to by the large military and civil affairs presence of UNMIL (United Nations Mission in Liberia), and the various donors present in the country. Currently land rights-related violence occurs in different parts of the country (NC, 2007; GOL, 2006; USAID, 2007; Unruh, 2007a). In some areas, gains made by UNMIL to enforce significant aspects of statutory land law, have been reversed as people return to illegal rubber tapping, squatting, and land resource extraction activities (USAID, 2007).

At present the land tenure situation in the country is severe. Richards (2005) notes that while perhaps 100,000 young people joined various armed factions during the war, there are several hundred thousand additional rural youths now in Liberia and neighboring Sierra Leone that are potentially vulnerable to similar mobilization. And that "[y]oung people without secure tenancy rights will continue to float in the countryside without stable social commitments, and thus remain vulnerable to both chiefs and militia recruiters" (Richards, 2005, 587). Likewise the UN indicates that "[t]housands of disarmed former fighters from Liberia's 14 year civil war are still roaming the country without training or reintegration into society, threatening Liberia's chances of future stability" (IRIN, 2007). Indeed "reform of rural rights seems as urgent an issue as tracking the gun-runners or diamond- and timber-smugglers" (Richards, 2005, 588).

This article offers an examination of the current land tenure situation in Liberia and considers approaches for attending to specific aggregate-level problems. Subsequent to a description of methods, and a land tenure overview of the country, the paper focuses on an analysis of specific types of land holdings and their associated problems. This is followed by an analysis of four primary problem sets in the context of a concluding 'way forward.' The literature on postwar land tenure is growing, and attends to important issues regarding the peace process, restitution, economic recovery, and the rule of law (e.g., CAS, 2006; Thomson, 2003; Leckie, 2003; Unruh, 2003). As well, a variety of case studies exist (Norfolk, 2004; Huggins, 2004; Cohen, 1993; Barquero, 2004; Bailliet, 2003). To date however there has been no examination of Liberia in a postwar land tenure context, despite the primary role land tenure played in the cause and maintenance of the war, and will play in meeting the challenges of the postwar socio-political environment and providing a foundation for durable peace and development. 


\section{Methods and geographic administration}

The field research comprised a series of individual and group interviews, and focus group discussions totaling 210 people in the months of December 2006 and February 2007 as part of land tenure policy reform work led by the Liberian Governance Reform Commission. Those interviewed included smallholder farmers, large landholders, ministry officials, university researchers, NGOs, lawyers, UN personnel, commercial agriculture associations, bilateral and multilateral donors, international legal and development organizations, and a former President of the country. As well a review of the relevant academic, Liberian government, NGO, legal, and donor literature took place.

The county is the primary sub-national administrative unit in Liberia, followed by districts and townships (Figure 1). Clans and chiefdoms are both administrative units with a kin aspect. Clans act as a set of local, customary institutions and play a role in land tenure, and clan leadership knows intimately the happenings in rural areas. Chiefdoms are spatial areas and constitute a group level customary land claim that connects with broader national understandings and institutions regarding land tenure. Chiefs are assisting with postwar reintegration and will continue to have significant local authority regarding land issues. Poro secret societies, whose influence is exclusive to the northeast of the country, can be general and fluidly defined spatial areas, and are reportedly of utility for governance issues including land tenure, in some ways. This may include social discipline (enforcement of land tenure decisions) but perhaps not resource allocation, and not in terms of transparency. There is some indication that Poro society institutional involvement in land conflicts tend to take one side or another, as opposed to operating in a way that objectively resolves such conflicts.

\section{Overview of land tenure in Liberia}

\subsection{Background}

Former American slaves were settled on the Liberian coast beginning in the $19^{\text {th }}$ century. With the arrival of the settlers, a statutory system of land tenure was established for areas under their control. The settler society was exclusive, and resided within an array of indigenous African coastal communities. All of these communities possessed land tenure systems that held land to be inalienable (Sawyer 2005). Nevertheless settlers interacting with indigenous communities pursued alienation of land (instead of use) made possible by a mix of violent conflict and alliance-making (Sawyer 2005). Settler acquisition of lands were supported by a variety of laws, including an early constitution (Sawyer 2005; Wiley 2007). While the indigenous lands on the coast appear to have been purchased, in the interior or 'hinterland' indigenous land was acquired through an extension of the 1847 constitution into the interior, together with its enabling laws (Wiley 2007). Customary law, based on usufruct rights, continued in interior areas inhabited by indigenous communities and administered as provinces by the Liberian state. The initial decades of the $20^{\text {th }}$ century saw often brutal subjugation of parts of the interior, with the resulting tensions between the Americo-Liberian settlers and indigenous inhabitants still reflected in current land issues. When the provinces became counties in the mid-twentieth century, 
the customary tenure system continued, and was sanctioned as a distinct system by the state (GRC, 2007). Some aspects of the customary tenure system were supported and changed to suit the state, while other aspects were neglected or declared illegal. The land law of 1956 primarily attends to Americo-Liberian settlers in areas they occupied. This was complicated by the emergence of what was known as the Kwi, indigenous Liberians regarded as 'civilized' who enjoyed special social status and property rights. All other land in the interior was, and continues to be, primarily occupied by indigenous Africans under customary land tenure; but is legally considered the property of the state and therefore public land (World Bank, 2007).

Smallholder agricultural use and political control of land was the tenurial focus until Firestone was established as the first rubber concession in the 1920s (GRC, 2007). The statutory tenure system then became the legal basis for the derivation of concessions for rubber, timber, and minerals. Such concessions were often foreign-controlled private commercial farms. Over time, increasing areas in rural Liberia were transferred from the customary system to the statutory tenure system by the acquisition of land deeds (through chiefs) by Americo-Liberians (GRC, 2007). Rampant land appropriation and land speculation eventually evolved into sources of acute uncertainty and conflict (GRC, 2007). By the outbreak of the civil war in 1990, the legal mechanisms for acquiring land deeds, especially in areas under customary tenure, was a seriously contentious and volatile issue (GRC, 2007).

\subsection{Confusion and ambiguity}

Currently the primary land tenure problem in the country as a whole is the massive confusion that exists on a range of legal, administrative, boundary, claim, and ownership issues. The link between such confusion and wide ranging land tenure insecurity is explicit (Bruce et al, 1994). With little clarity regarding different types of ownership, which rights are held by whom and how, how disputes are resolved, where boundaries exist, and who the authorities are in land matters, the resulting insecurity of claim, residence, food supply, and investments (small and large) is high. The result is a focus on short-term extractive activities that result in widespread land resource degradation. The administrative and judicial systems required to handle land matters in the postwar context are currently extremely underdeveloped, nonfunctional, or overstretched. Archival records were destroyed and looted during the war-with land deeds a specific target. There is a profound lack of trained personnel to manage the property rights system and to adjudicate disputes; and unauthorized surveyors are taking advantage of the fluid situation (GRC, 2007).

In a legal context, there is confusion regarding the overall status and application of polices and laws regarding land and property. Those that exist are unclear, lack effective implementing regulations, and are often very dated and so are not able to engage present Liberian reality. As well the existence of a good deal of received law from England via the US is unsuited to present Liberian reality. There is ambiguity and confusion regarding 
which laws have been applied in which cases and how, particularly with regard to the granting of concessions and resolution of disputes. Currently between 75 and 90 percent of all cases in all statutory courts (probate, civil, criminal, appellate) are land and property related (Unruh, 2007b; GRC, 2007). And land disputes are the most frequent cases in local courts (Richards, 2005). There is also considerable confusion regarding what constitutes legitimate evidence for land and property claims. This has led to a good deal of speculation, and the use of historical documents of varying degrees of relevancy and legitimacy. As well the court system constitutes a problematic and legally pluralistic arrangement for solving land and property disputes. There exists a confused variety of procedures depending on the actors, the context, and the issue at hand. In addition, no land use plan or policy exists stipulating what uses can go on where in the country. This leads to improvisation, and such improvised decisions will need to be taken into account when a land use plan is finally drawn up. There are also no legal working definitions of 'city', 'town', 'clan', and 'chiefdom' with regard to the land and property rules that apply to these.

Fraudulent, ambiguous, and multiple land transfers have created a great deal of confusion regarding who has legal rights to what lands, and how defensible these might be. And despite a new (postwar) inheritance law, there continues to be considerable confusion around issues of land inheritance - between siblings, children, and families. There is also a good deal of ambiguity about what rights are and are not included in a concession. Particularly important in this regard is the confused understanding about the right to exclude others (local communities) from a concession. Local communities are now contesting the allocation of land to concessions, including past allocations. Because considerable animosity was generated when the government issued concessions without consulting local communities, some of the current disputes involving concessions are explosive. Disputes over privately-held rubber farms are common, especially when original owners are absent (GRC, 2007).

The general non-clarity in land rights is aggravated by the existence of the dual tenure system in the country (statutory and customary). While such duality is not in itself a problem - such co-existence occurs in a large number of countries - in Liberia there are constant and persistent clashes involving customary versus statutory rights over the management, authority and control of land resources (GRC, 2007). The legal distinction between government land, public land, and aborigine or tribal land deeds lacks clarity and is being challenged (GRC, 2007). As well there is no legal or institutional mechanism whereby disputes and other issues can be resolved between tenure systems. In agriculture, the interface between commercial holdings and smallholder farmers is the focus of increasing conflict. As a result animosity and legal ambiguity is quite high and problematic. Tribal land is often claimed by outsiders, with the resulting disenfranchisement causing significant problems. 
Effective boundary demarcation is a large and confusing problem, not only for counties (and subunits), but for concessions, individual deed holders, tribal lands, and state and public lands. In a number of cases how much land exists in the various counties and concessions is unknown. In others, mistaken numbers are used to calculate such areas. One cause of this problem is that a great deal of redistricting has gone on in rural areas over the various previous government regimes, particularly during the conflict, for largely political reasons. Such changes were not adequately recorded as they occurred, including with regard to shared boundaries. Complicating this is that during the 1990s about half of the country was under the control of various armed factions and the government is just now coming to understand what has gone on in these locations regarding political and administrative change in units. Today there is often overlap and jurisdictional ambiguity between the state-supported customary units of clan and paramount chieftaincies, and the townships and cities subject to the statutory system (GRC, 2007). The overall situation is that sub-national boundaries exist in severe disarray.

Lastly there exists a great deal of ambiguity regarding the physical location of relevant laws, regulations, records, statistics and other documents after the war. While a great many of these have been destroyed and irretrievably scattered during the fighting, others exist in private residences or as part of small personal archives of those who worked or work in the various government, university and private offices. While the personal acquisition and possession of such documents during the war has provided a service to the country, in that it has prevented such documents from being permanently lost, presently there is considerable difficulty in locating and gaining access to these much needed documents.

\subsection{Social relations}

A good number of respondents from the fieldwork indicated that the war has changed much in Liberia, including social relations about land. Much in customary life has changed, and this is reflected in changed approaches to land and property rights. The broader problem is that a great deal of land tenure decisions need to be and are made by the general population as a matter of the social relations of day to day life. The need for such decisions, and the interpersonal binding agreements that follow, do not wait for laws, policies, or plans to be drawn up.

Acute societal divisiveness is common after conflict, with such divisions usually always embodying land issues (Unruh, 2003). Some of those spoken with indicated that a number of issues central to the war have translated into land issues after the war. Postwar Liberia has seen divisions emerge or become aggravated between Americo-Liberians and indigenous Liberians, a Muslim - Christian divide, and tribalism emphasized, particularly with regard to the Mandingo ethnic group specifically over land and property issues. While the history of the Mandingo problem has been described elsewhere (e.g. Richards, et al. 2004), the essence of the issue resides in whether the Mandingos are to be considered citizens of Liberia or not, and thereby able (or not) to legitimately claim, own, 
and occupy land. While the Mandingos have been in Liberia for generations, neighboring ethnic groups can insist that they are not legitimate Liberians and should 'return' to Guinea. One primary aspect of the problem are conflicts emerging between adverse possession claims via statutory law by Mandingos, and traditional claim by other ethnic groups. This has come about because during the war LURD (a militia opposed to Charles Taylor) recruited significant numbers of Mandingo, to the degree that LURD was seen by some groups as a Mandingo movement. As LURD took over much of the interior to the north and west of Monrovia, other groups fled allowing Mandingo families to engage in squatting on land and property belonging to these groups. The aggravation of the Mandingo non-Mandingo divisions due to the war stems in part from the reliance on close kin for survival, as other networks of social reciprocity collapsed during the course of the conflict. This is a common postwar feature in Africa (Unruh, 1995a; 2004; 2006).

Women's issues have come to the fore with regard to the land question, primarily in terms of land access and inheritance, with these two being intertwined. In this regard women tend to have less rights in land under customary law than under statutory law. In 2003 a group of women lawyers in Monrovia, the Association of Female Lawyers of Liberia (AFLL) worked to help pass a new law, 'An Act to Govern the Devolution of Estates and Establish Rights of Inheritance for Spouses of Both Statutory and Customary Marriages' (MoFA, 2003). The outcome of this law is that inheritance of land for women is now legally the same under statutory and customary law. ${ }^{1}$ The impact of the new law and the dissemination work of the AFLL on customary law regarding women, inheritance, and land, appears to be variable. The new inheritance law has received resistance from some rural men (and some parliamentarians) who would like to keep the previous customary inheritance arrangement intact. However others have accepted the new arrangement. In this regard AFLL has noted that Muslim areas are more open to the new inheritance law than other areas.

Land rights are also a concern for some refugees and internally dislocated persons (IDPs) in terms of community and tribal land. This can connect with an ethnic dimension with regard to who is or should be attached to which lands. As well there can in some locations be a divide between those who stayed and those who fled as a result of the war, with regard to reintegration, land use, reclaim, and eviction. Land access is one of the problems why many remaining refugees and IDPs have not yet returned to areas of origin. This remaining group, its size, location, current occupation, and precise reasons for land in-access may become increasingly problematic as recovery proceeds. Sierra Leone has experienced significant ongoing problems in this regard (ICG, 2004; Unruh, 2005a).

\footnotetext{
${ }^{1}$ Subsequent to passage of the law AFLL created a simplified version and delivered it and other information regarding the law in rural workshops, to rural women's groups, and distributed cassettes to local radio stations containing messages about the new law in the form of songs and drama.
} 


\section{Land holding types and associated problems}

This section analyzes the current problems with the different types of landholdings within the formal and customary tenure systems in Liberia after the war. While there is a comparative difference in tenure security between the types of holdings, all suffer from extremely poor tenure security.

\subsection{Formal statutory land holdings}

\subsubsection{Deed holdings}

Liberia has a statutory land tenure system based on the issuance of deeds. For individuals participating in the formal land tenure system, land is held in fee simple. This arrangement emerged from the earliest settlers (freed American slaves) who could be allotted either a town parcel or 25 acres of farmland per married couple. Under the deed system only the number of acres and general boundaries were recorded. The lack of a registry in land means that no record system exists whereby one can determine the true owner of land, to whom all or part has been sold, boundary locations, inheritance, the role and validity of historical deeds, and fraud. This puts the legitimate deed holder in an extremely vulnerable position, and a potential buyer or renter in an even more vulnerable position. Thus a deed holder selling a portion of a holding would still hold the deed for the entire, original holding. The result has been the repeated sale and resale of the same lands over time (World Bank, 2007) leading to the present pervasive confusion over who owns what lands. This has created a situation whereby opportunists are able to purposefully make multiple sales regarding the same land, with little or no repercussions. Thus this is a variation of the 'culture of impunity' that exists after a war. The result is an enormous postwar surge in land and property dispute cases in all types of courts. In aggregate this means that deed holders who are involved in a dispute, or think that others might in any way have a counter-claim, will be less willing to adopt long-term technologies or investments associated with longer term productive strategies. Other problems with deeds include confusion over the different types of deeds, problems with adjudication including enforcement of decisions, the theft of deeds during the war and their fraudulent use, and destruction and loss of deeds. Overall these problems have resulted in a significant decrease in the value of a deed as a piece of evidence (in the proving of claim). Thus the deed provides extremely poor tenure security in the current institutional and socio-political environment.

An additional issue which combines with the problematic value of a deed as evidence for land claim, is the interaction between deeds and tree crops, with the latter also functioning as a form of claim. While the connection between planting economic trees and land claim is not included in formal law as a way to acquire land, it is nonetheless a very strong notion in the customary sector, including for customary farmers with deeds. Such that even a deed holder will not allow a tenant or borrower of land to plant trees for fear that they may be used as an attempt to claim the land. This is an important interaction between formal law (deeds) and customary law (tree crops equal land claim), because it acts as a significant constraint on both tenure security and technology 
(agroforestry) adoption (Unruh, 2002a). The broader implications of such a reduced value and legitimacy for deeds as a form of evidence or 'proof of claim' is that now counter claims, and the act of contesting or challenging deed holders over a claim (with either legitimate or fraudulent intentions) is much more accepted, easily done, and common. This occurs because the decrease in the value of the deed as evidence results in the comparative rise in perceived value of other forms of evidence-testimony, the existence of tree crops, buildings and other improvements, and land clearing.

As an example of the above, the fieldwork revealed a variety of documents in circulation in rural areas that are used as evidence of claim to land holdings, apparently quite secure locally, although of questionable formal legal standing. There exist numerous cases where local forms of 'deeds' have been issued at the district level by various government and customary authorities even though this is not allowed in law. These are used as forms of claim, and together with robust tree crop planting by smallholders involved in customary holdings, appear to be fairly secure internal to local communities.

An additional problem with deeds and documents is poor demarcation. The surveys that have taken place in the course of issuing deeds have in a great many cases been carried out in an incomplete and haphazard manner. In such cases, only one boundary, for example along a road, was often surveyed, and then the instruction by the surveyor to the deed applicant was to "take 300 acres away from the road" with the subsequent boundaries at both the far end of the 300 acres and along the sides of the demarcation left unsurveyed. This leaves it up to the deed applicant to estimate where the allocation's boundaries are. The result is a large number of boundary disputes.

\subsubsection{Concessions}

Concessions for access and exploitation of natural resources (primarily rubber, timber, oil palm and minerals) comprise a complex set of problems. Foremost among these is the considerable confusion about what rights are included or excluded with regard to concession holders. There is a widespread understanding that a concession, while issued for the purpose of exploiting specific resources such as timber, rubber, minerals, or agriculture, has in practice been used to pursue a very broad set of rights to claim and exploit land resources in whatever way suits the concession holder--although it may have little to do with the business proposal that was used to obtain the concession. As well there are significant problems with the actual areas granted as concessions-with the total area granted in some counties exceeding the area of the county itself. There seems to be little connection between the area granted or held, and the area to be developed. Frequently the concession areas granted were much larger than the area actually developed for rubber, agriculture, or mineral exploitation. Such that the mismatch between area granted to a concession holder, and the area then developed, is quite large, amounting to hundreds of thousands of acres claimed (to the exclusion of others, including local communities) but not used. In one case a concession was granted for 650,000 acres, but only 5,000 acres was developed. Nevertheless the claim for the full 
650,000 acres is maintained and others are excluded from the land. Such land is essentially not accessible for other investment, nor can it play a role in local to national food security, even as concessions often occupy the best land. The situation also aggravates the problems between concession holders and local communities, with many of the latter now questioning the legitimacy of the transfer of customary lands to concession held lands - both historically and currently. There is ongoing confusion and disagreement over who has had the authority to grant concessions, particularly since there has historically been a problem consulting local communities.

One of the more serious problems in the concession areas is the ongoing presence of excombatants (in some cases still armed) camped in the plantations. Some of these groups are illegally tapping rubber trees and selling the latex, or mining, while other groups are hired by plantation owners to protect the plantation and exclude local communities, and still other groups appear to report to former militia commanders for a variety of reasons. One oil palm plantation in Sinoe County has up to 10,000 people on the property engaged in small-scale diamond and gold mining (USAID, 2007). At the same time those concession holders who are returning, want access to their concessions so as to re-engage in effective production again. As a result security is a very large problem on many concessions (e.g. USAID, 2007). Resolving the presence of ex-combatants on concessions will be a delicate part of the peace process. Presently the price of rubber is high, and so encourages extra-legal tapping and makes more difficult the regularization of rubber holdings.

Timber concessions have received significant attention in Liberia due to the international sanctions on Liberian timber imposed by the UN Security Council during the war. The natural forest on all land in the country, including private land, belongs to the government and can be allocated under timber concession arrangements. Thus in Liberia the owner of land and the owner of trees are distinct. Recent efforts to have the sanctions lifted, and international assistance in this regard have led to a great deal of legal (including enforcement) effort regarding timber concessions in Liberia; including change in how timber concessions are granted. The Transitional Government of Liberia established the Forest Concession Review Committee which recommended the cancellation of all concessions. The Sirleaf presidency accepted the recommendations and cancelled all forestry concessions through Executive Order \#1 in February 2006, which also established the Forest Reform Monitoring Committee. These efforts have resulted in the new National Forestry Reform Law of 2006, and the Forestry Development Authority (FDA) Draft Regulations and Contracts ${ }^{2}$.

\footnotetext{
2 These FDA regulations are important to fulfilling the UN Security Council conditions for lifting all timber sanctions against Liberia. One aspect of these regulations provides for establishing a 'chain of custody' regarding timber as to location, the specific concession, etc., such that legality and taxes can be determined.
} 
Significant changes have also occurred with regard to the relationship between forestry concessions and local communities. As part of the new forestry law, a new concession cannot be granted without obtaining permission from the local community. As well, a new forestry concession must enter into a 'social agreement' with local communities. Additionally, land rental fees are subject to a benefit-sharing arrangement in which the concessionaire pays 30 percent of the land rental to local communities, and another 30 percent to county, with the remainder going to the Ministries. While the 'community' aspect of the Forestry Law is well intentioned, who counts as a member within a community and importantly who speaks on behalf of a community is left ill-defined and has a seriously problematic history. Prior to the war the relationship between the state and those who sought to represent communities was a source of serious structural corruption involving local leadership and the Presidency (Liebenow 1969).

\subsection{Customary and other informal land holdings}

There is no written customary land law in Liberia. However, all lands in the designated indigenous areas come under a system of tenure based on traditional customary law. Within this system, there is no individual ownership, but instead the state recognizes certain communal rights to land, but not others. As a result, individuals have land use rights but cannot own land. Land is under the control of the chief who has a communal deed to tribal areas and administers its distribution. The size of the area farmed by a household depends on family size and labor requirements. In the early 1980s, the average subsistence household of five to seven people cultivated three acres of upland rice and one to two acres of other crops. Americo-Liberian settlers and indigenous Liberians tied to statutory law can purchase communal lands, but first must go to the chief to get permission and pay a token of good intention. The chief then signs a certificate that the purchaser takes to the District Commissioner who is the Land Commissioner for the area. If the land is not a portion of the Tribal Reserve, nor is it owned or occupied by another person, a certificate can be issued. Revenues are then paid to the Bureau of Revenues at the rate of 50 cents an acre and an official receipt is then attached to an application to be given to the President of the country. The President then decides whether to approve the application, and will order the surveyor to survey the site. After this, all documents receive the President's signature and a deed for the customary land can be obtained (World Bank, 2007). The role of the Presidency in recognizing land claims and approving allocations facilitates important source of patronage. Liebenow (1969) describes the historical cult of the presidency in Liberia, and how the office was seen as instrumental in preserving privilege.

The customary tenure sector has played a large and generally positive role in the reintegration and resettlement of dislocatees after the war. There are however several issues of significant concern. Important among these is the profound lack of confidence among smallholders regarding customary courts and their inability to fairly adjudicate land issues. This has led to an increase in 'trial by ordeal' for many issues including land conflicts. Trail by ordeal in Liberia involves (among several approaches) use of 
poisonous plant materials applied to an individual in various ways with the result indicating innocence or guilt. As well the prohibitions against making improvements by renters or 'borrowers,' and specifically prohibitions against tree crop planting, are strong. This is due to the fear by those who hold land customarily, that tenants and others will attempt to use improvements as evidence supporting a permanent claim to the lands in question. This fear acts as a disincentive to allow 'strangers' onto customary land for rental or loaning in the first place. The result is that land goes uncultivated, strangers are without land, and food security (local to national) is compromised. An important concern is the potential reinstatement of certain abuses by customary leadership (in partnership with the state), particularly with regard to land access for migrant youth. Extremely exploitive arrangements existed prior to the war, and a more equitable institutional relationship between customary leadership, youth needing land access, and the state should be a priority in postwar governance.

A good deal of the transactions and dispute problems in the community and tribal areas stem from those who have deeds or some form of documentation versus those who do not. Maryland county in the south of the country is a particular problem in this regard. One of the processes leading to this situation is the granting of land when a new road is built, and the adjoining land then becomes valuable. Those who have the means and are connected to the statutory legal system can purchase such lands, own them in fee simple, and then determine on their own which communities or individuals already occupying the land can stay or must depart. As well, the new owner can set conditions by which the community occupants can stay, including labor, rent, etc. Those community members who depart then move further away from the new road and onto land already claimed customarily by others, causing another set of disputes.

Tenancies are a significantly insecure form of customary holding, and the smallest infraction can see the renter evicted. For tenants, their comparative insecurity relegates them to annual crops only, with tree crops or other forms of permanent improvements again specifically prohibited. Often rented land, when it does occur, is only for one cropping season in order to ensure that permanent claims will not be pursued, and conflicts are frequent. Most often rented and leased land only occurs between neighbors and relatives who know each other well and are able to operationalize forms of informal trust. Leasing, renting, and lending land among people who are not familiar with each other is very rare. This is due to the very low capacity of the legal structure to enforce contracts, and the low trust in the legal structure by customary smallholders, particularly after the war. Meanwhile those who do rent or lease land note that if the annual crop is too successful, the agreement can frequently be broken and the owner can retake the land including the standing crop, and the tenant is evicted. This is a strong disincentive to make even temporary investments in land. Overall, the occurrence of renting/leasing land is very low in rural Liberia, with communities reporting a range of different situations. The range extends from rental/leasing is 'possible but does not often occur', to 'it never occurs', to arrangements being 'broken often', and conflicts erupting over rental and 
leasing engagements. The leasing problem has a significant impact on the ability of rural youth to (re)integrate into farming. Many young people are unwilling to return to home areas where they feel they would be vulnerable to manipulation by elders, especially regarding land and marriage (Richards 2005). Thus the development of secure leasing arrangements involving 'strangers' from elsewhere in the country should be a priority. County officials such as Superintendents could play a significant role here by overseeing the security of such leases. While it may be tempting for the state to claim and allocate (via leasing or otherwise) apparently unoccupied land in an attempt to resolve renting and labor problems, unoccupied land does not equal unclaimed land. And the intrusion of the state onto such lands in the past using 'unoccupied equals unclaimed' as the logic, has led to serious problems in the current postwar context.

There are a variety of land related informal institutions in postwar Liberia that pertain to specific groups, but are not regarded as 'customary'. These can be referred to as local, informal, postwar 'micro rule of law' systems (Plunkett, 2005). The emergence of such systems during and subsequent to armed conflict is common (Plunkett, 2005; Unruh, 2003). The informal derivation of a variety of approaches to acquiring, (re)establishing, securing, defending, and proving claims to property, land, homeland, and territory during and after a war parallels the general fracturing of societies into smaller war and postwar communities of shared experience, dislocation and (re)location (Hohe, 2005; Junne and Verkoren, 2005; Kamphuis, 2005; Sorensen, 1998). Plunket (2005: 79) elaborates specifically how micro rule of law systems come about during and subsequent to conflict, "[t]he priority given by an individual to a rule system may be radically altered during times of war, particularly where the state is fractured, frustrated, or collapsed. While the official will assert allegiance to the authority of the state or to 'his group,' an individual is likely to have a complete reverse of priority or rule observance, especially when the state is weakening or has collapsed."

The extent to which these systems prove to be positive contributions to postwar land tenure reform or, instead create problems or otherwise operate more neutrally, remains to be seen. Some of these micro rule of law systems regarding informal forms of land tenure include, squatters, ex-combatants, refugees and internally displaced persons, rural youth, women's groups, specific ethnic groups, religious divisions, etc. Squatters as a group are particularly problematic and are dealt with separately below.

Squatted holdings constitute a large and difficult problem in both rural and urban areas of Liberia. In some cases squatters can be the most aggressive in pursuing forms of land claim involving tree planting or other improvements, or through adverse possession. The latter can be legally pursued in Liberia after 20 years of occupation of someone else's land, with no attempt by the property owner to evict. There is some discussion among the legal sector in Monrovia as to whether the 14 year civil war period can be counted toward the 20 year period regarding adverse possession claims. The prospect of the war period counting toward such claims is causing serious concern among current returning deed holders, many of whom are politically and/or financially in a position to forcibly evict 
squatters on their land. Such eviction could occur soon because many adverse possession claims using the 14 year war period will be viable within the next few years. Eviction of squatters risks social unrest if carried out on a large scale or in numerous instances, is very visible, or if it involves ex-combatants. Tenure security is so low for squatters that in many cases they can have little to lose, and so can attempt to claim land in the hopes that any resulting dispute will result in some form of compensation at a minimum. As well, such low tenure security can also result in rural squatted holdings being subject to extractive, resource degrading activities such as illegal timber and rubber harvesting.

\section{The way forward}

The way forward for Liberia in a land tenure context comprises attention on several fronts. This section builds on the previous sections by suggesting approaches for four aggregate issues, 1) the need to attend to the very large volume of legal cases in the courts involving disputes, restitution, etc; 2) the time problem; 3 ); the evidence problem; and, 4) a set of issues related to the dual (formal and customary) land tenure system in the country.

\subsection{Attending to a postwar 'surge' in tenure problems}

A priority in Liberia's land tenure recovery and policy reform efforts is a reduction in the very large volume of outstanding legal cases involving disputes, claims problems, evidentiary issues, boundary problems, and restitution; as well as a reduction in the time and money involved in dealing with these. At present land cases are severely clogging the court system (Banks, 2007) thereby degrading the delivery of justice more broadly than on just land and property matters. This is a serious difficulty following a war when the promotion of the rule of law, and increased access to justice are priorities in the peace process.

In postwar Liberia it is not realistic to pursue an approach that seeks to untangle the history of transactions and actions which led to each individual land dispute, given the enormous number of disputes lodged in the court system and the low postwar capacity of the legal system to handle these. While some cases involving acute (particularly securityrelated) problems, and high-profile cases would need particular attention with regard to what went on when, where, and with whom, in most cases and on many topics this is not possible, particularly in a timely manner. While one approach to pursuing resolution of a large volume of land cases is to establish separate land courts or tribunals that are seen as fair, legitimate, and effective, these can take a considerable period of time to derive, finance, staff and operate - often years. A different option is to categorize the different types of disputes and other problems, and then pursue a resolution for the category. Mozambique and East Timor have experienced considerable success with this approach (Unruh, 2006; 2005b). Such a 'category approach' seeks to delineate categories of problems, or types of similar cases, and then provide a legal approach (such as a legal ruling) to deal with the category. This has the advantage of quickly reducing the overload on courts, as well as the time, money, and effort needed to go through each and every 
case individually. As an example, disputes involving transactions made in bad faith can be dealt with in such a 'batch' format. And, a legal ruling on the applicability of the 14 year war period in adverse possession claims would reduce this particular caseload in a similar manner. Liberia has just accomplished a form of this 'category approach' in deciding to cancel and review all forestry concessions as a category of landholding. Such categories of cases and issues can be as narrowly defined and as numerous as deemed necessary to capture the important differences between sets of problems, and to deal with certain problems equitably and in a short time frame. While not all tenure problems can be dealt with in this manner, it does have the effect of significantly reducing the volume of cases after a war (Unruh, 2002b).

\subsection{The time problem}

There is a significant time issue with regard to land tenure after conflicts, and Liberia is an important example of this. Subsequent to a war there is a legal, capacity, financial, administrative, and infrastructure vacuum, during which individuals and groups make decisions regarding various aspects of land and property rights. It is important for a peace process to influence aspects of this vacuum so that events and processes do not develop into severe problems. Thus while it takes time to derive new laws and policies, managing the period between the end of the war and when new laws and policies can be implemented is important. In this regard government needs to be seen as active in the overall land issue by the population at large. Such an activity can be accomplished in a variety of ways, including the 'category' approach noted above. As well, conferences and workshops for stakeholders at different levels and in different locations in the country can be of utility in this regard. These can also be part of the needed consultative process important to policy formation in land tenure (Unruh, 2003; 2005). More broadly, such a vacuum is more quickly filled by pursuing a law-making approach that involves enacting in sequence, several land and property laws on specific topics (as in East Timor), as opposed to a single, all encompassing land law which takes much more time (as in Angola and Mozambique).

\subsection{The evidence problem}

Evidence for proving claims to land and property is a pervasive problem after wars and in Liberia in particular. The legal need to untangle the transactions history of the large volume of disputes in the country originates from the need to determine which claimant(s) have (or had) a preponderance of evidence in their favor, so as to determine who should get legitimate ownership and/or access to what lands. Over-reliance on the need for documentary evidence in such cases can cause significant problems, as it does in Liberia. Other countries emerging from conflict (Mozambique, Sierra Leone, East Timor) have found utility in re-working evidence rules, to allow a very wide variety of evidence into attestations of claim (Unruh, 2006). In Mozambique customary evidence involving testimony (parol evidence) became equal to possession of a title in land disputes after the war-with positive results (Unruh, 2005b). While in a strict, legally deterministic sense it may be argued that equating documentary evidence to forms of customary evidence can 
detract from the integrity of the document in matters relating to land and property, such a concern is out of place where most do not have documentary evidence, and very much out of place after prolonged armed conflict. At the same time it is well within the Western legal tradition (where Liberia's own formal legal history resides) to hold that 'relevancy' is the primary evidence rule in civil cases (Dennis, 1999; Murphy, 2003; Robillard, et al. 2002). With such a rule guiding the admission of evidence, and a wide variety of formal and informal evidence therefore admissible, both East Timor and Mozambique have found that many disputes became 'self-resolving' out of court (due to the fear by one or both parties that they might lose the claim entirely), thus sidestepping in many cases the problem of lack of access to courts (Unruh, 2006).

\subsection{The dual land tenure system}

Virtually every country in Africa has both statutory and customary land tenure systems, and the presence of parallel systems exists as well in a number of developed countries. Such duality per se is not problematic, but rather the way it is handled. In Liberia there needs to be much more mutual recognition and connection between the two systems than there presently is. The purposeful separation of the two systems over a long period of time has led to their non-integration, discrimination against the customary system when they do come into contact, and has prevented the evolution of positive and mutually beneficial ways of interacting. As well, the lack of a robust effort by Liberian researchers over time, particularly lawyers, to derive innovative ways in which the two systems can interact, has further isolated them from each other in functioning, recognition, and integration. In this regard the Liberian Law Journal needs to be revived and provided with assistance so as to constitute a link that takes on issues such as the co-evolution of the formal and informal tenure system (e.g. Allot, 1967). The reporting in such journals in other countries is used in deriving innovative approaches to legal and policy problems (including between formal and customary land tenure), and communicating these to the legal establishment.

New land and property laws and policies in Liberia would do well to pursue a connection with customary forms of land tenure, particularly in terms of court systems; evidence; levels of dispute resolution and appeal structure; claim; consultation; and issuance of concessions, titles, and deeds. Such an effort can coincide with efforts at decentralization. The advantage of encouraging such connection is that the state will then not be burdened with attempting to administer and enforce land and property laws in all areas of the country - which it will not be able to do in any case. Thus recognizing and cooperating with customary law in non-discriminatory ways, and encouraging equitable interaction, offers the advantage of obtaining a free good by the government — an administrative structure, capacity and functioning already located in rural Liberia at no cost to the state.

Such a connection between formal and customary tenure systems is however different than re-instituting aspects of the state sanctioned customary tenure system that contributed to the onset of war. The customary tenure system itself needs to evolve to 
meet the current needs of its population, including an ability to interact effectively with state law. It can be argued that the isolation of the customary sector and its neglect, together with the lack of awareness of legal developments in other African countries by both the customary and formal legal domains in Liberia, has led to the stagnation of forms of law and practice regarding land tenure (among other issues), and the resulting problems with rural youth and women being unable to gain land access. As well, the lack of connection that could have resulted in considerable positive co-evolution between the two tenure systems is what has led to the persistence of the non-consultative approach of government when issuing concessions, titles, and deeds, as well as the claim that all rural land belongs to the government.

Neighboring Sierra Leone has the position of a 'customary law officer' in a number of rural areas, which functions at the interface between the two legal systems. While there is a need to strengthen this in rural Sierra Leone, the example is instructive in terms of how to build a better flow of information, cases, examples, decisions, needs, and aspirations between the two tenure systems over time, thus assisting them to become more exposed to each other, and to co-evolve. Zambia also employs such an approach in a quite a successful way with its 'Law Development Commission'.

\section{Final note}

Land and property laws and approaches that best serve a stable society over the longterm, and that facilitate capital formation and capital movement with regard to land and property (e.g. de Soto, 2000), are not able to manage a postwar land tenure environment effectively and in a timely manner. While the derivation and implementation of such (stable) laws and policies is of course a necessary goal, there must also be legal approaches able to deal with the host of complicated issues regarding land tenure after a war. These need to come on-line prior to the derivation of policies and laws that are more suited to well functioning banks, a private sector, cadastres, underlying policies, enforcement, equity, and a legitimate and effective court system, as well as the capacity to operate all these. A case in point is the necessity to derive secure leasing and rental arrangements for rural youth with legal enforcement constructs that are able to be implemented much quicker and more locally than the derivation and implementation of national lawmaking would allow.

In a postwar environment issues of retribution; profound inequality in land and property; legal pluralism that favors some sectors of society over others in land matters or that add confusion; the presence of non-reintegrated ex-combatants and others; a legal system that is non-inclusive; and grievances and animosities, along with other postwar issues, need attention much sooner than the implementation of 'stability assuming' tenure approaches can provide. Awareness and understanding of such problems and how they operate with regard to Liberia is important to the derivation of an effective land and property rights system able to meet the challenges of a postwar socio-political environment, and provide a foundation for durable peace and development. 


\section{References}

Allott, A.N. 1967. A report on the feasibility of research into Liberian customary law. Liberian Law Journal 3, 83-100.

Bailliet, C. 2003. Property restitution in Guatemala: a transnational dilemma. In: Leckie S (Ed.), Returning Home: Housing and Property Restitution Rights of Refugees and Displaced Persons. Transnational Publishers, Ardsley. NY

Banks, P. 2007. Issues paper on reforming Liberia's legal and judicial system towards enhancing the rule of law. Governance Reform Commission, Republic of Liberia, Monrovia

Banks, P. 2006. Personal communication, legal advisor. Governance Reform Commission, Government of Liberia, Monrovia

Barquero, R. 2004. Access to land in post-conflict situations: a case study in Nicaragua. FAO, Rome

Bruce, J.W., and Migot-Adholla, S.E. 1994. Searching for Land Tenure Security in Africa. The World Bank and Kendall/Hunt Publishing Co, Dubuque, Iowa

Center for Advanced Study (CAS) 2006. Justice for the poor, an exploratory study of collective grievances over land and local governance in Cambodia. Center for Advanced Study, World Bank, Phnom Phen.

Cohen, S.E. 1993. The Politics of Planting: Israeli-Palestinian Competition for Control of Land in the Jerusalem Periphery. Geography Research Paper No. 236, University of Chicago Press, Chicago.

Daygbor, J. 2007. Land dispute - country's next war trigger. The Analyst (Monrovia) AllAfrica Global Media. Monrovia. 21 March

Dennis, I. 1999. The Law of Evidence. Sweet and Maxwell, London.

Governance Reform Commission (GRC) 2007. The way forward: land \& property right issues in the republic of Liberia. Governance Reform Commission, Government of Liberia, Monrovia

Government of Liberia (GOL) 2006. Liberia statement of policy intent for agriculture. Ministry of Agriculture, Government of Liberia, Monrovia 
Hohe, T. 2005. Developing local governance. In: Junne. G., and Verkoren, W. (Eds.), Postconflict Development: Meeting New Challenges. Lynne Rienner, Boulder

Huggins, C. 2004. Land access issues in post-genocide Rwanda. Food and Agriculture Organization of the United Nations, Rome.

International Crisis Group (ICG) 2004. Liberia and Sierra Leone: rebuilding failed states. Crisis Group Africa Report No. 87, Brussels.

IRIN. 2007. Liberia: donor fatigue threatening DDR process. UN Office for the Coordination of Humanitarian Affairs.

Johnson, K. 2007. Personal communication. Professor of Law, School of Law, University of Liberia, Monrovia.

Junne, G., and Verkoren, W. (2005) The challenges of postconflict development. In: Junne, G., and Verkoren, W. (Eds.), Postconflict Development: Meeting New Challenges. Lynne Rienner, Boulder.

Kamphuis, B. 2005. Economic policy for building peace. In: Junne, G., and Verkoren, W. (Eds.), Postconflict Development: Meeting New Challenges, Lynne Rienner, Boulder

Leckie, S. 2003. New directions in housing and property restitution. In: Leckie, S. (Ed.), Returning Home: Housing and Property Restitution Rights of Refugees and Displaced Persons. Transnational Publishers, Ardsley NY.

Norfolk, S. 2004. Examining access to natural resources and linkages to sustainable livelihoods: a case study of Mozambique. LSP Working Paper 17, FAO, Rome.

Ministry of Foreign Affairs (MoFA) 2003. An act to govern the devolution of estates and establish rights of inheritance for spouses of both statutory and customary marriages.

Ministry of Foreign Affairs, Monrovia, Liberia

Murphy, P. 2003. Evidence, Proof, and Facts. Oxford University Press, Oxford.

National Chronicle (NC) 2007. In Firestone shooting: two security personnel wounded. National Chronicle, February 19, Monrovia.

Plunkett, M. 2005. Reestablishing the rule of law. In: Junne, G., and Verkoren, W. (Eds.) Postconflict Development: Meeting New Challenges. Lynne Rienner, Boulder.

Richards, P. 2005. To fight or to farm? agrarian dimensions of the Mano River conflicts (Liberia and Sierra Leone). African Affairs 105, 571-590. 
Richards, P., Archibald, S., Bruce, B., Modad, W., Mulbah, E., Varpilah, T., Vincent, J. 2004. Community cohesion in Liberia: a post-conflict rapid social assessment. African Knowledge Associates, Monrovia.

Robillard, W.G., Wilson, D.A., Brown, C.M. 2002. Evidence and Procedures for Boundary Location. Fourth Edition. John Wiley and Sons, New York.

Sawyer, A. 2005. Beyond Plunder: Toward Democratic Governance in Liberia. Lynne Rienner Publishers, London

Sorensen, B. 1998. Women and postconflict reconstruction: issues and sources. WSP Occasional Paper no 3, June.

de Soto, H. 2000. The Mystery of Capital: Why Capitalism Triumphs in the West and Fails Everywhere Else. Basic Books, New York.

Thomson, N. 2003. Access to land in post-conflict situations: an analytical paper. FAO Rome.

Unruh, J.D. 2006. Land tenure and the 'evidence landscape' in developing countries. Annals of the Association of American Geographers. 96, 754-772.

Unruh, J.D. 2005a. Land tenure and its relationship to food security and investment in postwar Sierra Leone. Food and Agriculture Organization of the United Nations, Rome.

Unruh, J.D. 2005b. Property restitution laws in a post-war context: the case of Mozambique. African Journal of Legal Studies 3, 147-165.

Unruh, J.D. 2007a. Land tenure and agriculture in postwar Liberia. Comprehensive Assessment of the Agriculture Sector in Liberia. World Bank, Washington, DC.

Unruh, J.D. 2007b. Postwar land tenure in Liberia: lessons learned from other postconflict countries. World Bank, Washington DC.

Unruh, J.D. 2003. Land tenure and legal pluralism in the peace process. Peace and Change: A Journal of Peace Research 28, 352-376

Unruh, J.D. 1995a. Post-conflict recovery of African agriculture: the role of 'critical resource' tenure. Ambio 24: 343-350 
Unruh, J.D. 2002a. Land dispute resolution in Mozambique: evidence and institutions of agroforestry technology adoption. In: Meinzen-Dick, R., Mcculloch, A., Place, F., Swallow, B. (Eds.) Innovation in Natural Resource Management: The Role of Property Rights and Collective Action in Developing Countries, Johns Hopkins University Press, London.

Unruh, J.D. 2002b. Local land tenure in the peace process. Peace Review 14, 337-342.

Unruh, J.D. 2004. Post-conflict land tenure and the sustainable livelihoods approach. Food and Agriculture Organization of the United Nations, Rome.

USAID. 2007. Liberia: poor infrastructure, law enforcement hinder Sinoe regional economy. US Agency for International Development, Unclassified Cable 00000670, Monrovia.

World Bank. 2007. Concept note Liberia: the role of land tenure in confronting the challenges of transition - a strategic plan for accelerating growth and investment in the urban and rural sectors. World Bank, Washington, DC.

Wiley L (2007) So who owns the forest? An investigation into forest ownership and customary land rights in Liberia. The Sustainable Development Institute, Monrovia

Zelze, E. 2007. Personal communication. Commercial business owner, Monrovia. 